KINETICS AND THERMODYNAMIC STUDIES ON REMOVAL ... 109

KINETICS AND THERMODYNAMIC STUDIES ON REMOVAL OF

COPPER METAL ION FROM AQUEOUS SOLUTION USING RICE STRAW

A. A. EL- ZOMRAWY, M. THABET*, M. B. AWAD, A. M. SWALEM, M. ABO-

SHOUK

Department of Chemistry, Faculty of Science, Al-Azhar University, Cairo, Egypt

E-mail address: thabet1972@yahoo.com

\begin{abstract}
The adsorption percentage of $\mathrm{Cu}(\mathrm{II})$ ions from aqueous solution in the absence and in the presence of different concentration of hydrochloric acid on rice straw (SIII) and its ash (R400) were studied in a modified batch adsorption technique. The kinetic data was analyzed using various kinetic models particularly pseudo-first-order, pseudo-second-order and intra-particle diffusion. The pseudo-second-order kinetic model was found to agree well with the experimental data. Thermodynamic parameters such as enthalpy $\left(\Delta H^{\circ}\right)$, free energy $\left(\Delta G^{\circ}\right)$ and entropy $\left(\Delta S^{\circ}\right)$ changes towards calculated and adsorption process was spontaneous at R400 in the absence and in the presence of $0.005 \mathrm{M} \mathrm{HCl}$ and exothermic in nature.
\end{abstract}

Keywords: Copper; rice straw; removal

\title{
Introduction
}

Heavy metal ions can be released into wastewater from various industries such as metal finishing, electroplating, battery manufacturing, steel industries, tannery, paint manufacturing, electronic industries, etc. [1]. Copper is known to be one of the most toxic to living organisms and it is one of the more widespread heavy metal contaminants of the environment [2-6].

Copper can be removed by precipitation as copper hydroxide but this method is only efficient in alkaline media. One of the interesting methods which have been employed to remove copper from wastewater are membrane separation, electrochemical treatment, reverse osmosis and solvent extraction [7]. All these methods are generally expensive; therefore it is important to search for a low-cost method which is effective and economic. Recently, the adsorbents based on natural products and their derivatives have gained particular attention, e.g. sawdust [8-10], sugar beet pulp [11, 12], rice husk [9, 13-18], treated rice husk [19], orange waste [20], bamboo charcoal [21], and treated orange waste [22].

Many researchers have been investigated agriculture bi-product as adsorbents for removal of copper metal ion [5, 12, 23-32]. The main objective of this study is to assess the effectiveness of rice straw and its ash in the removal of copper by 
determining the efficiency of adsorption in the absence and in the presence of different concentration of $\mathrm{HCl}$ solutions.

\section{Our research:}

\section{Materials and methods}

\section{Instrumentation}

AAS Vario 6 Analytik Jena atomic adsorption spectrometer operating with an air acetylene flame was used to determine the concentration of $\mathrm{Cu}(\mathrm{II})$. Five standard solutions with concentrations of copper metal ions in the linear range of the instrument were used to construct each calibration curve. During analysis of the samples for copper metal ions concentration, those samples in which the concentration of copper ions is observed beyond the linear range of the references were diluted to appropriate concentrations.

The $\mathrm{pH}$ of the solution was measured with a microprocessor $\mathrm{pH}$ Meter ( $\mathrm{PH} 211)$ using HANNA electrode (HI1230) calibrated with standard buffer solutions of $\mathrm{pH}$ values: 4,7 and 10.

\section{Adsorbate Solution}

Stock solution of copper metal ions was freshly prepared by dissolving required quantity of Analar grade salts in the distilled water. The salts used are copper sulfate for the preparation of stock solution. The stock solution was further diluted with distilled water to desired concentration for obtaining the test solutions.

\section{Adsorbent: adjustment of adsorber}

To prepare the rice straws, they were initially ground and homogenized using a food blender with steel blades for 10 min. Particle sizes $\leq 212$ mesh (SIII), were obtained by passing the milled material through a steel sieve. Also SIII of rice straws was burn-off at $400{ }^{\circ} \mathrm{C}(\mathrm{R} 400)$.

\section{Mechanism adsorption studies}

Batch process was employed for adsorption studies. A $0.5 \mathrm{~g}$ adsorbent was placed in a polypropylene bottle having $100 \mathrm{ml}$ of $\mathrm{Cu}$ (II) solution. The mixture was then filtered at predetermined time interval and the final concentration of metal ions was determined in the filtrate by Atomic Absorption Spectrophotometer. Amount of $\mathrm{Cu}$ (II) adsorbed was then calculated by subtracting final concentration from initial 
KINETICS AND THERMODYNAMIC STUDIES ON REMOVAL ... 111 concentration. Adsorption studies were carried out by varying the adsorbate concentration (10 $\mathrm{mg} \mathrm{l}^{-1}$ ), the agitation time (3-180 min), and adsorbent amount (0.5 g).

The amount of copper adsorbed, $q_{\mathrm{e}}\left(\mathrm{mg} \mathrm{g}^{-1}\right)$ was computed by using the following equation:

$$
q_{e}=\frac{C_{0}-C_{e}}{m} V
$$

Where $C_{0}$ and $C_{\mathrm{e}}$ are copper ion concentrations $\left(\mathrm{mg} \mathrm{L}^{-1}\right)$ before and after adsorption, $V$ is the volume of adsorbate (L) and $m$ is the mass of the adsorbent (g). The percent removal of copper ion is calculated by the following equation:

$$
\operatorname{Removal}(\%)=\frac{C_{0}-C_{e}}{C_{0}} \times 100
$$

\section{Effect of temperature}

Equilibrium adsorption of $\mathrm{Cu}(\mathrm{II})$ ions was performed at five different temperatures such as $25,30,35,40,45{ }^{\circ} \mathrm{C}$ in absence and presence of $0.005 \mathrm{M}$ hydrochloric acid solution. Dose of $0.5 \mathrm{~g}$ of SIII, or R400 of rice was firstly weighed accurately and introduced directly into $250 \mathrm{ml}$ polypropylene bottle. Then, $100 \mathrm{ml}$ of aqueous solutions containing metal ions with $10 \mathrm{mg} / \mathrm{l}$ concentration were added to each bottle and shacked till 3 hrs. to attain the equilibrium. The concentration of the residual aqueous phase was determined using an atomic absorption spectrophotometer.

\section{Results and discussion:}

\section{Efficiency of adsorbent}

\section{Effect of acid concentration}

Table. 1 shows the effect of $\mathrm{pH}$ on the adsorption efficiency of SIII and R400 for copper metal ion. The amount of adsorption is calculated after three hours as batch techniques. It is seen from table that amount of adsorption of copper ions by SIII in aqueous solution in absence of acid is $72.9 \%$, whereas the adsorption in presence of $0.01 \mathrm{M} \mathrm{HCl}$ reaches to (43.3\%), and reaches to (11.98\%) with increasing of $0.05 \mathrm{M} \mathrm{HCl}$. The decreasing in uptake at higher concentration of acid may be due to the affect of anionic group to $\mathrm{H}^{+}$ions on the surface of adsorbent, due to restricting the number of binding sites for metal ions [33]. 
The adsorption amount of $\mathrm{Cu}$ (II) with samples $\mathrm{R} 400$ and $\mathrm{R} 400+\mathrm{HCl}$, is higher than that in the raw sample, this may be attributed to appearance of silanol group $(\mathrm{Si}-\mathrm{OH})$ on the surface of adsorber after ignition, this group may act as Lewis basis in deprotonated form (Si-O-) to bind with Lewis metal ions such as $\mathrm{Cu}(\mathrm{II})$ and Cd(II), Hence, this metal ions can form more monodentate or bidentate complexes with $\mathrm{Si}-\mathrm{O}-$ group[34].

\section{Effect of temperature}

Fig.1. shows the effect of the increasing temperature on the adsorption of copper ions on SIII, R400 in the absence and in the presence of hydrochloric acid (0.005M) were studied by employs the adsorption experiments in a temperature range of 25$45^{\circ} \mathrm{C}$ with agitating through time of 3 hours.

An increase in the temperature from 35 to $45{ }^{\circ} \mathrm{C}$ leads to an decrease in the efficiency of adsorption of copper ions onto SIII. The decrease in adsorption capacity of SIII with temperature indicates an exothermic process. The effect of temperature on $\mathrm{Cu}(\mathrm{II})$ adsorption on $\mathrm{SIII}+0.005 \mathrm{M} \mathrm{HCl}$ can be inferred from figure 1 . From the figure it can be observed that, when the temperature of the solution is changed from 25 to $45^{\circ} \mathrm{C}$, the amount of $\mathrm{Cu}(\mathrm{II})$ ions adsorbed slightly decreased,

The equilibrium adsorption capacity of $\mathrm{Cu}(\mathrm{II})$ ions onto R400 and R400+ $0.005 \mathrm{M} \mathrm{HCl}$ were favored at low temperatures.

Table 1:Efficiency of copper ions adsorption on SIII, R400 in the absence and in the presence of deferent concentration of $\mathrm{HCl}$ at $25^{\circ} \mathrm{C}$.

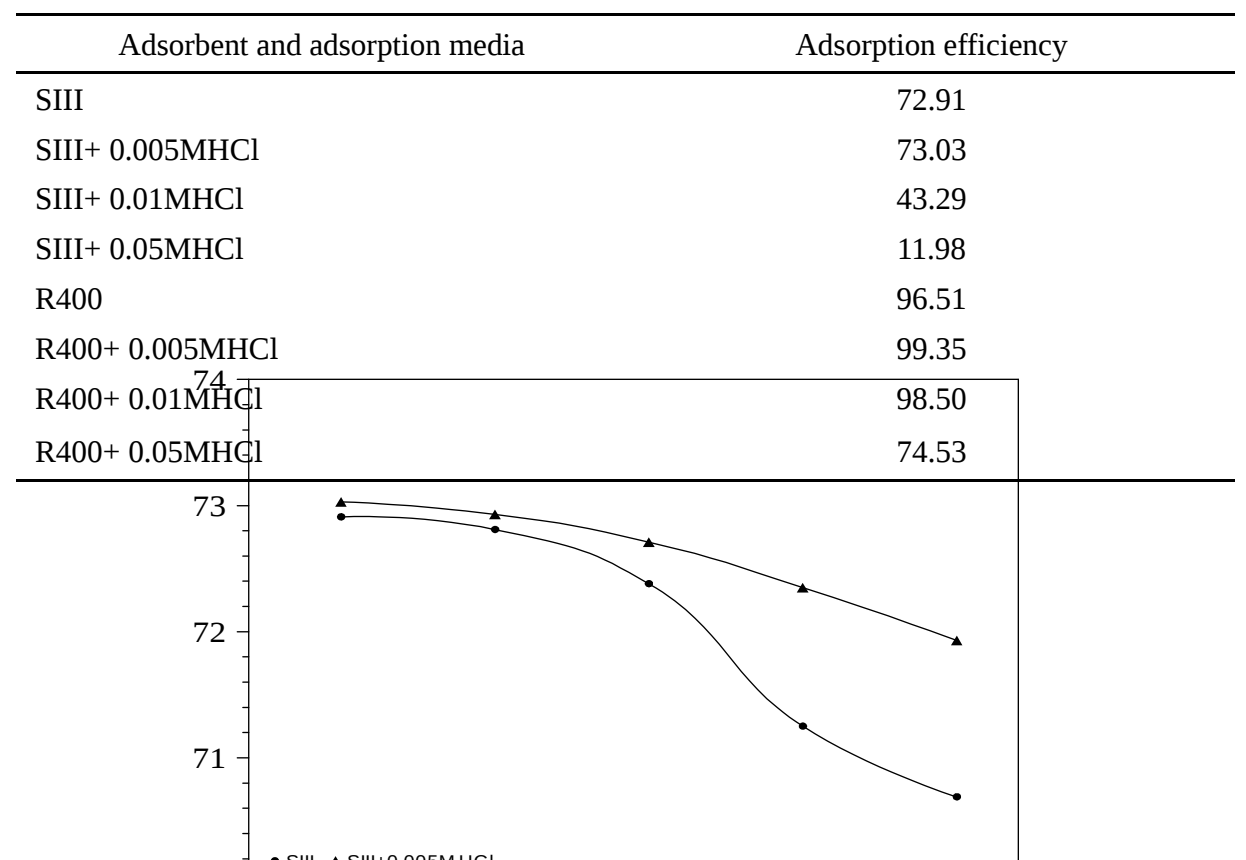




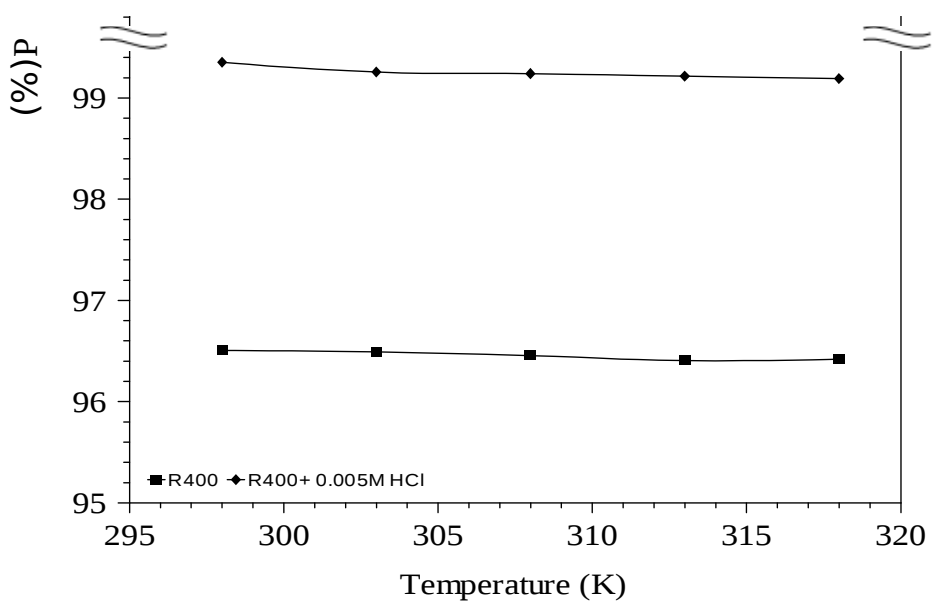

Fig.1. Effect of temperature on efficiency of copper ions

\section{Data Evaluation}

Pseudo-first-order and pseudo-second-order reaction rate model [35 - 38] were employed to study the copper adsorption onto SIII, R400 in absence and presence of $0.005 \mathrm{M}$ hydrochloric acid solution at $25{ }^{\circ} \mathrm{C}$. The mathematical representations of models are given in Eqs. (3) and (4).

Pseudo first-order adsorption kinetic model:

$$
\ln \left(q_{e}-q_{t}\right)=\ln q_{e}-k_{1} t
$$

The adsorption rate constant $\left(k_{1}\right)$ were calculated from the slope of the linear plot of $\ln \left(q_{\mathrm{e}}-q_{\mathrm{t}}\right)$ versus time.

Pseudo second-order adsorption kinetic model:

$$
\frac{t}{q_{t}}=\frac{1}{k_{2} q_{e}^{2}}+\frac{1}{q_{e}} t
$$

Kinetic data were plotted between $t / q_{\mathrm{t}}$ against $t$. 
The pseudo-first-order adsorption rate constant $k_{1}$ from the slopes and $q_{e}$ can be calculated from the intercept from Figs. 2,3. The corresponding values of $k_{1}, q_{e}$ and $r^{2}$ are presented in Table 2 at tested temperature. As can be seen from the results, the correlation coefficients were low $\left(r^{2}<0.90\right)$. Also $q_{e}$ values calculated from the plots were lower than the experimental data. Therefore, it may conclude that copper adsorption system did not follow pseudo-first-order equation perfectly and higher orders rate equations should be applied to test the applicability.

The pseudo-second-order adsorption rate constant $k_{2}$ and $q_{e}$ were determined from the slope and intercept of the plot. The values $k_{2}$, calculated $q_{e}$ values and the correlation coefficients $r^{2}$ are given in Table 2 and Figs. 4,5 shows the plots with initial copper concentration $10 \mathrm{mg} / \mathrm{L}$ at tested temperatures. As can be seen from the results that the correlation coefficients $r^{2}$ were high $(>0.99)$. The well fitting by the data suggested that pseudo-second-order model can be considered in the present adsorption system.

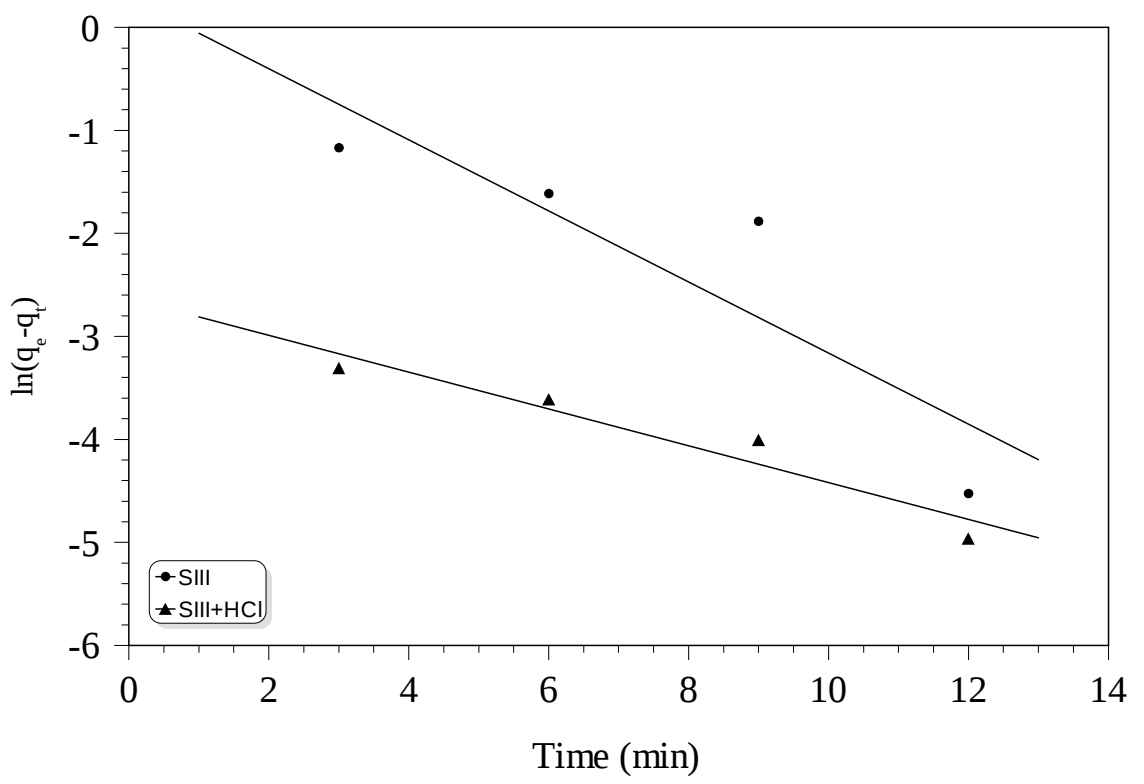

Fig. 2. Linear fitting curves of $\ln \left(q_{e}-q_{t}\right)$ versus $t$ for the copper ions adsorption onto SIII Rice in the absence and in the presence of $0.005 \mathrm{M} \mathrm{HCl}$ at $25{ }^{\circ} \mathrm{C}$. 
KINETICS AND THERMODYNAMIC STUDIES ON REMOVAL ... 115

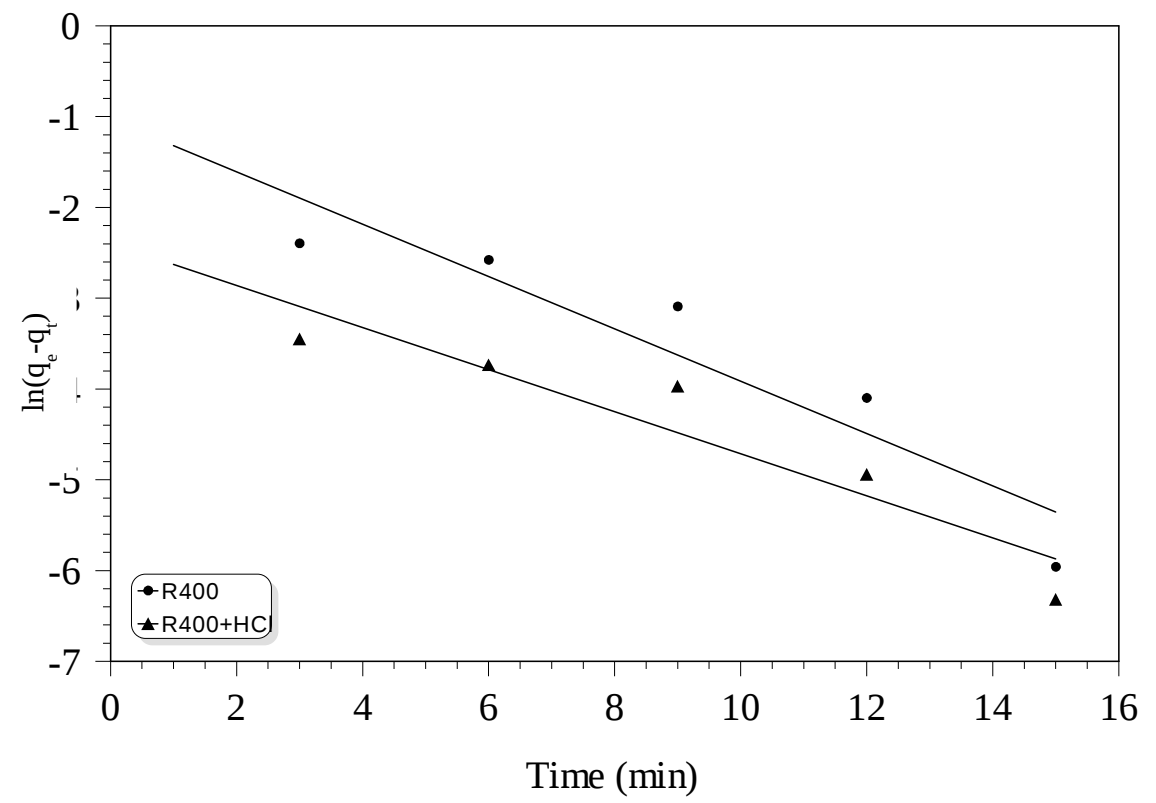

Fig. 3. Linear fitting curves of $\ln \left(q_{e}-q_{t}\right)$ versus $t$ for the copper ions adsorption onto .ignited rice at $400{ }^{\circ} \mathrm{C}$ in the absence and in the presence of $0.005 \mathrm{M} \mathrm{HCl}$ at $25^{\circ} \mathrm{C}$

Table 2. Comparison of the pseudo-first-order, and pseudo-second-order calculated and experimental $q_{\mathrm{e}}$ values at $25^{\circ} \mathrm{C}$.

\begin{tabular}{|c|c|c|c|c|c|c|c|c|c|}
\hline & & \multicolumn{4}{|c|}{ Pseudo-first order } & \multicolumn{4}{|c|}{ Pseudo-second order } \\
\hline & $\begin{array}{c}q_{\text {e, exp }} \\
(\mathrm{mg} \\
\left.\mathrm{g}^{-1}\right)\end{array}$ & $\begin{array}{c}q_{e, c a l} \\
(\mathrm{mg} \\
\left.\mathrm{g}^{-1}\right)\end{array}$ & $\begin{array}{c}k_{1} \\
\left(\mathrm{~min}^{-1}\right)\end{array}$ & $\begin{array}{c}t_{1 / 2} \\
(\mathrm{~min})\end{array}$ & $r^{2}$ & $\begin{array}{l}q_{e, c a l} \\
(\mathrm{mg} \\
\left.\mathrm{g}^{-1}\right)\end{array}$ & $\begin{array}{c}k_{2} \\
\left(\mathrm{~g} \mathrm{mg}^{-}\right. \\
\left.{ }^{1} \mathrm{~min}^{-1}\right)\end{array}$ & $\begin{array}{c}t_{1 / 2} \\
(\mathrm{~min})\end{array}$ & $r^{2}$ \\
\hline $\begin{array}{c}\text { SIII } \\
Z \\
\text { Цू } \\
\text { \& }\end{array}$ & 1.76 & 1.33 & 0.3448 & 2.01 & 0.7771 & 1.86 & 0.0515 & 1.0453 & 0.99416 \\
\hline 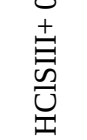 & 1.79 & 0.07 & 0.1786 & 3.88 & 0.9245 & 1.80 & 0.6552 & 0.0850 & 0.99997 \\
\hline $\begin{array}{c}\text { R400 } \\
Z \\
\text { L } \\
8 \\
0\end{array}$ & 1.94 & 0.36 & 0.2882 & 2.40 & 0.8733 & 1.97 & 0.1896 & 0.2678 & 0.99981 \\
\hline 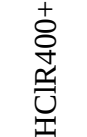 & 1.99 & 0.09 & 0.2318 & 2.99 & 0.8820 & 2.00 & 0.6011 & 0.0833 & 0.99998 \\
\hline
\end{tabular}


11

A. A. EL- ZOMRAWY, et al.,

6 


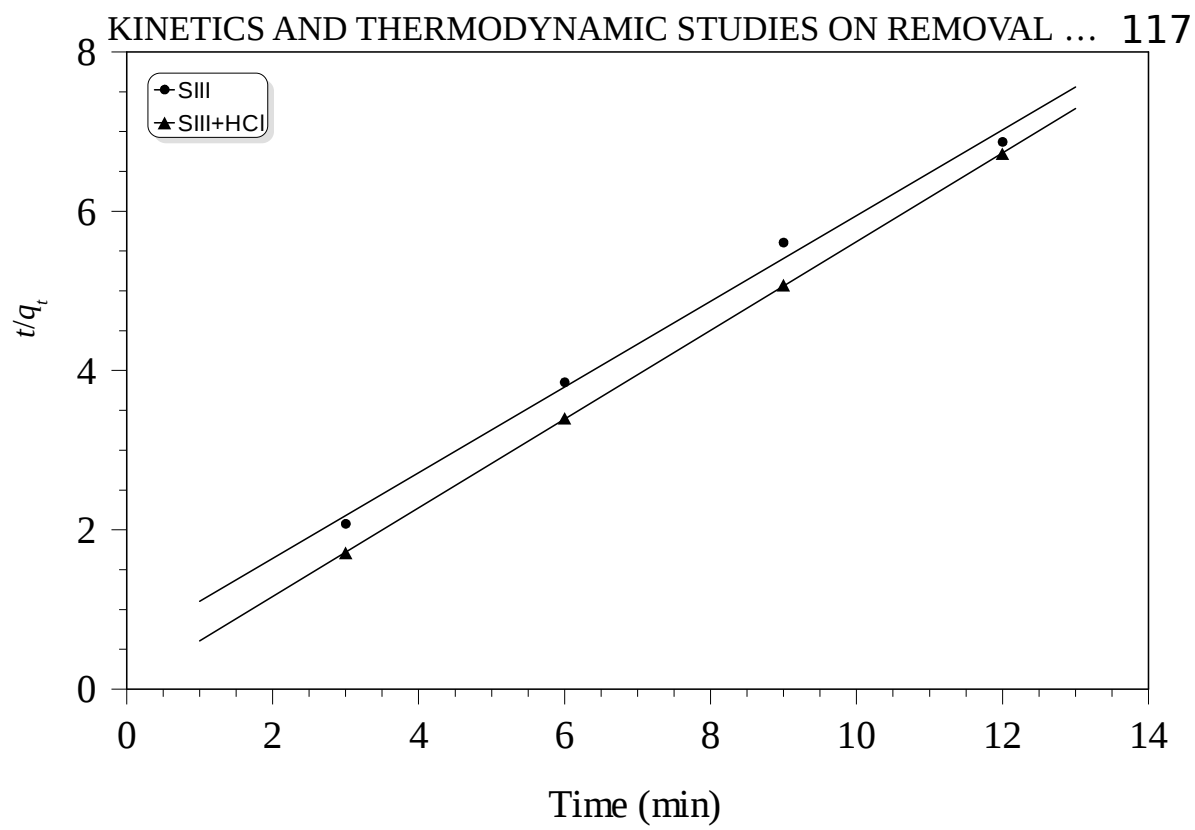

Fig. 4. Linear fitting curves of $t / q_{t}$ versus $t$ for the copper ions adsorption onto SIII rice in the absence and in the presence of $0.005 \mathrm{M} \mathrm{HCl}$ at $25^{\circ} \mathrm{C}$.

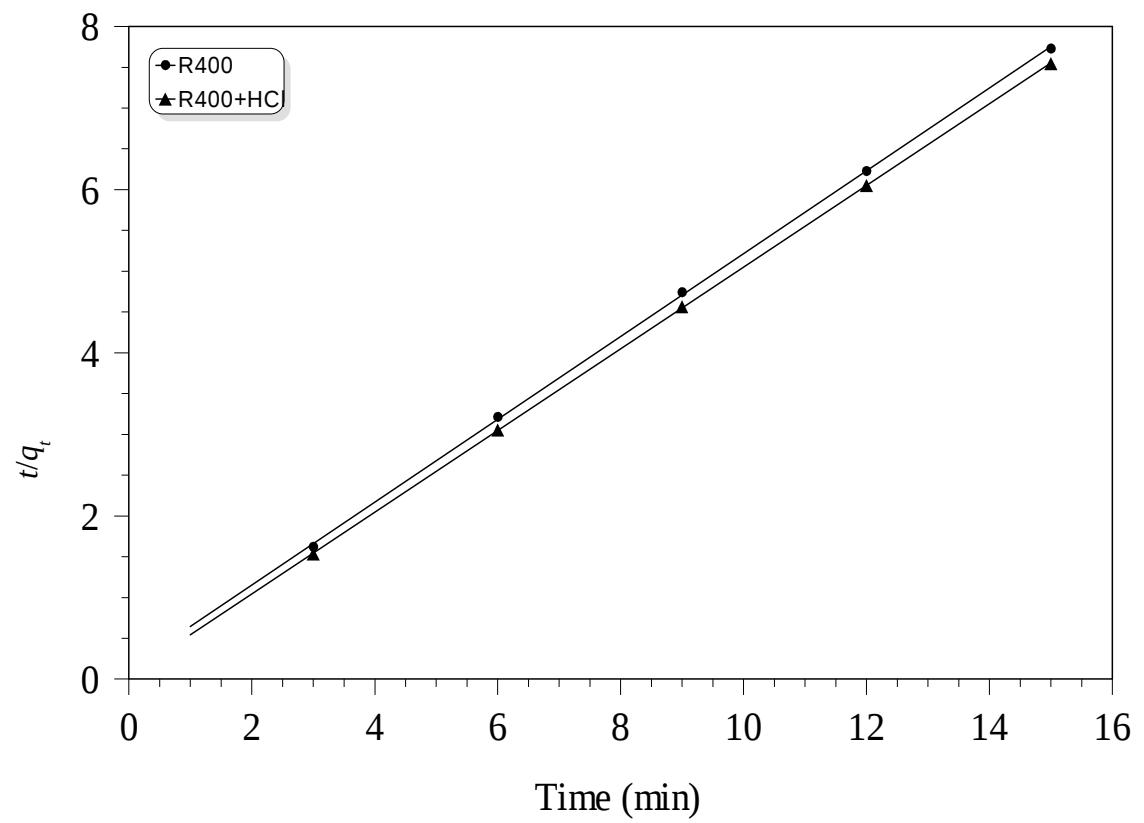

Fig. 5. Linear fitting curves of $t / q_{t}$ versus $t$ for the copper ions adsorption onto ignited wood at $400{ }^{\circ} \mathrm{C}$ in the absence and in the presence of $0.005 \mathrm{M} \mathrm{HCl}$ at $25^{\circ} \mathrm{C}$. 


\section{Adsorption mechanisms}

The first-order and pseudo-second-order models cannot identify the diffusion mechanism. For this reason, the kinetic results were then subjected to analyze by the intraparticle diffusion model. Mathematical model described by Weber and Morris [39] was used to provide the definite adsorption mechanism. According to this model, the plot of uptake, $q_{t}$, versus the square root of time $\left(t^{1 / 2}\right)$ should be linear if the intraparticle diffusion is involved in the adsorption process and if these lines pass through the origin then intraparticle diffusion is the rate controlling step. The initial curved portion of the plots seems to be due to boundary layer adsorption and the linear portion to intraparticle diffusion, with the plateau corresponding to equilibrium [40-43].

Intraparticle diffusion model is of major concern because it is rate-determining step in the liquid adsorption systems. During the batch mode of operation, there was a possibility of transport of sorbate species into the pores of sorbent, which is often the rate controlling step.

The rate constants of intraparticle diffusion $\left(k_{i d}\right)$ were determined using the following equation:

$$
q_{t}=k_{i d} t^{1 / 2}
$$

where $q_{t}$ is the amount sorbed at time $t$ and $t^{1 / 2}$ is the square root of the time.

The plot of $q_{t}$ against $t^{1 / 2}$ would result in a straight line if the rate limiting is the intra-particle diffusion. Moreover, the line would pass through the origin if the intraparticle diffusion is the only rate controlling step. The result of linearity test of $q_{t}$ against $t^{1 / 2}$ is shown in Figs. 6,7. In the present study, the plots of $q_{t}$ against $t^{1 / 2}$ obtained from copper removal onto SIII and R400 in absence and presence of 0.005 $\mathrm{M}$ hydrochloric acid did not pass through the origin and were not linear over the whole time range. The linearity was evaluated separately. For the first proportion, diffusion model was that mass of copper ions transferred across the bulk solution to the solution around adsorbent surface and the second linearity showed copper ions diffusion into adsorbent surface pores. The higher slopes for the first proportion implied that copper ions transferred from bulk solution to biochar surface were faster. The lower slopes of the second proportion suggested intra-particle diffusion was rate-controlling step after a long contact time. 
KINETICS AND THERMODYNAMIC STUDIES ON REMOVAL ... 119

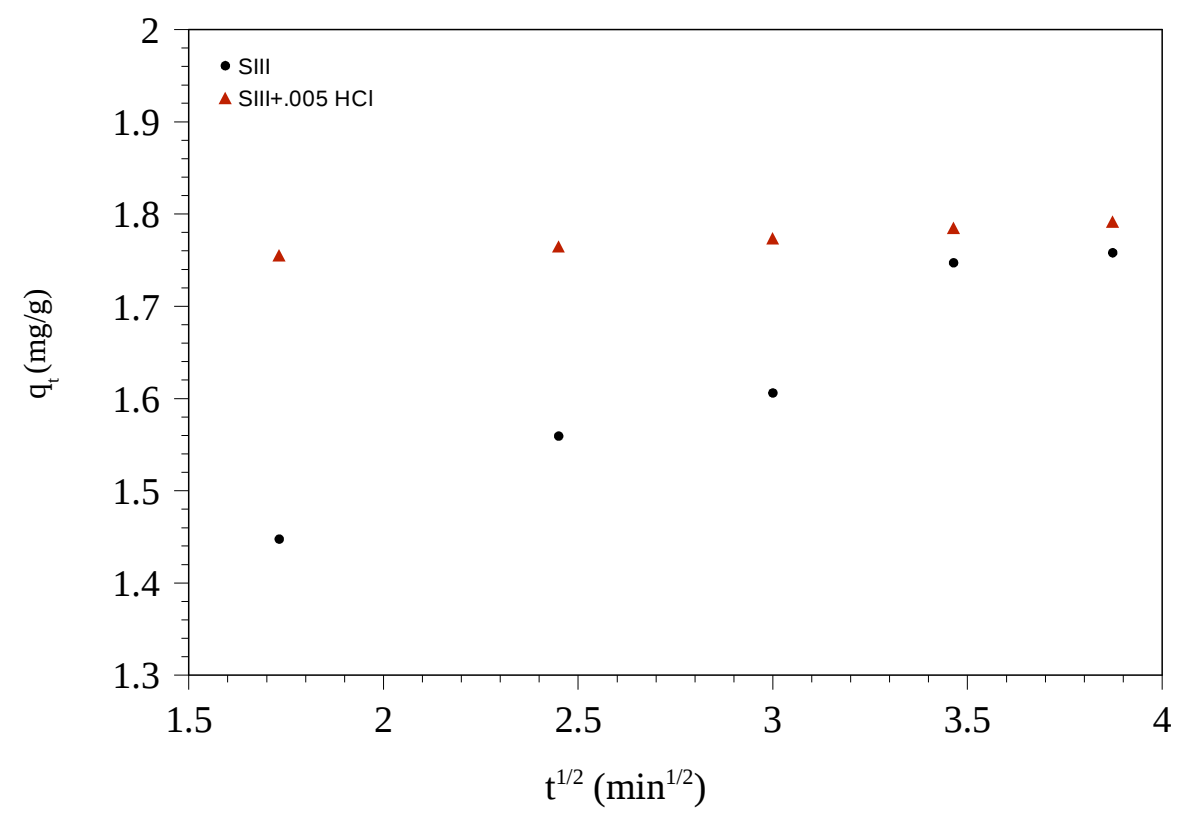

Fig. 6. Weber and Morris (intraparticle diffusion) plot for the adsorption of $\mathrm{Cu}$ (II) by $\mathrm{SIII}$ in the absence and in the presence of $0.005 \mathrm{M} \mathrm{HCl}$ at $25^{\circ} \mathrm{C}$.

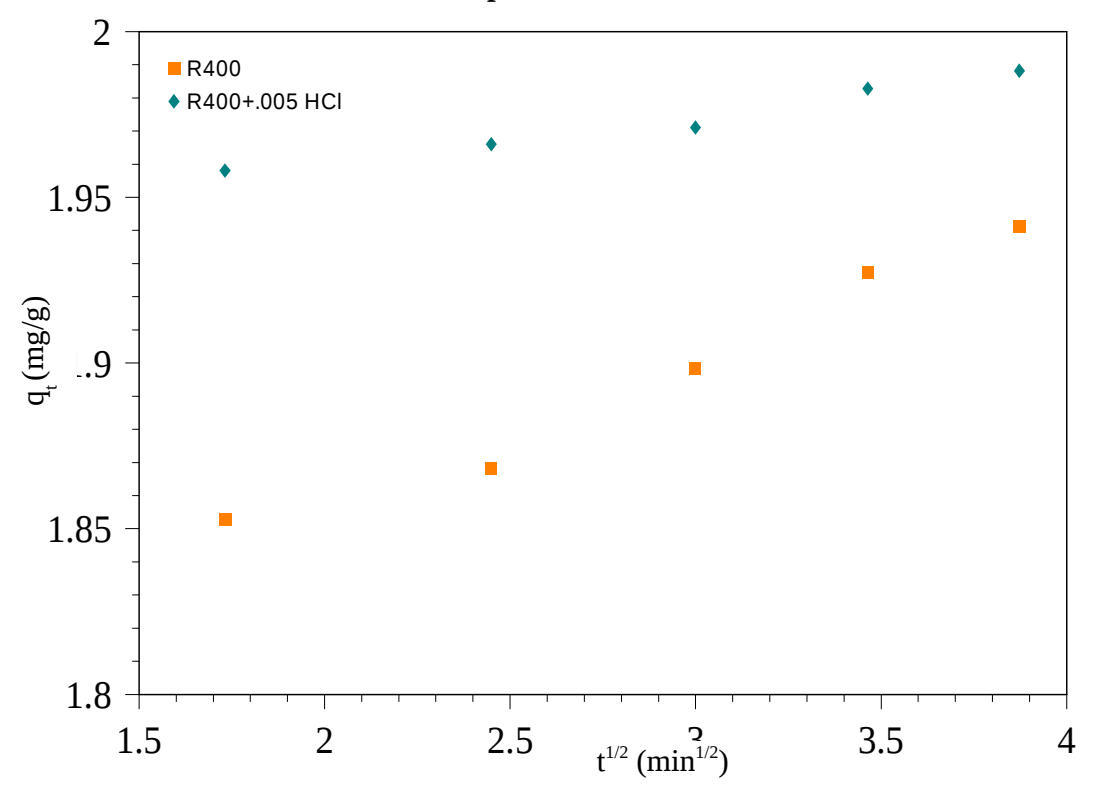

Fig. 7. Weber and Morris (intraparticle diffusion) plot for the adsorption of $\mathrm{Cu}(\mathrm{II})$ by $\mathrm{R} 400$ in the absence and in the presence of $0.005 \mathrm{M} \mathrm{HCl}$ at $25^{\circ} \mathrm{C}$. 


\section{Adsorption Thermodynamics}

Thermodynamic parameters, including Gibbs free energy change $\left(\Delta G^{\circ}\right)$, enthalpy change $\left(\Delta H^{\circ}\right)$, and entropy change $\left(\Delta S^{\circ}\right)$ were used to decide whether the adsorption process is spontaneous or not. $\Delta G^{\circ}$ were calculated from the following equation;

$$
\Delta \mathrm{G}^{\circ}=-\mathrm{RT} \ln K_{\mathrm{D}}
$$

Where $R$ is the universal gas constant ( $8.314 \mathrm{~J} \mathrm{~mol}^{-1} \mathrm{~K}^{-1}$ ), $T$ is the temperature $(K)$, and $K_{\mathrm{D}}$ is the distribution coefficient. The $K_{\mathrm{D}}$ value was calculated using following equation [44];

$$
K_{D}=\frac{q_{e}}{C_{e}}
$$

Where $q_{e}$ and $C_{e}$ are the equilibrium concentration of metal ions on adsorbent (mg $\mathrm{L}^{-1}$ ) and in the solution (mg L ${ }^{-1}$ ), respectively. Relation between $\Delta G^{\circ}, \Delta H^{\circ}$ and $\Delta S^{\circ}$ can be expressed by the following equation;

$$
\Delta \mathrm{G}^{\circ}=\Delta \mathrm{H}^{\circ}-\mathrm{T} \Delta \mathrm{S}^{\circ}
$$

This equation can be written as;

$$
\ln K_{D}=\frac{\Delta S^{\circ}}{R}-\frac{\Delta H^{\circ}}{R T}
$$

Thermodynamic parameters, $\Delta H^{\circ}$ and $\Delta S^{\circ}$, were calculated from the slope and intercept of the plot of $\ln K_{\mathrm{D}}$ versus $1 / T$, respectively.

The effect of temperature on the adsorption of copper metal ions onto SIII, R400 in absence and presence of $0.005 \mathrm{M}$ hydrochloric acid solution are given from the plots and curves of the distribution coefficient values $K_{\mathrm{D}}$ versus temperatures in Figs.8,9. It can be found that $K_{\mathrm{D}}$ slightly decreased with temperature increasing, a certification of the exothermic adsorption nature.

As the temperature increases, the mobility of copper ions increases causing the ions to escape from the solid phase to the liquid phase. Therefore, the amount of copper that can be adsorbed will decrease.

The results were further substantiated by the various thermodynamic parameters evaluated of adsorption, such as free energy, $\Delta \mathrm{G}^{\circ}$, enthalpy change, $\Delta \mathrm{H}^{\circ}$, and entropy change, $\Delta S^{\circ}$.

For significant adsorption to occur, the free energy change of adsorption, $\Delta \mathrm{G}^{\circ}$, must be negative. The adsorption of $\mathrm{Cu}$ (II) onto all adsorbate is exothermic in 


\section{KINETICS AND THERMODYNAMIC STUDIES ON REMOVAL ... 121}

nature, giving a negative values of $\Delta \mathrm{H}^{\circ}$. Hence, $\Delta \mathrm{S}^{\circ}$ has to be positive in R400 in absence 
A. A. EL- ZOMRAWY, et al.,

2

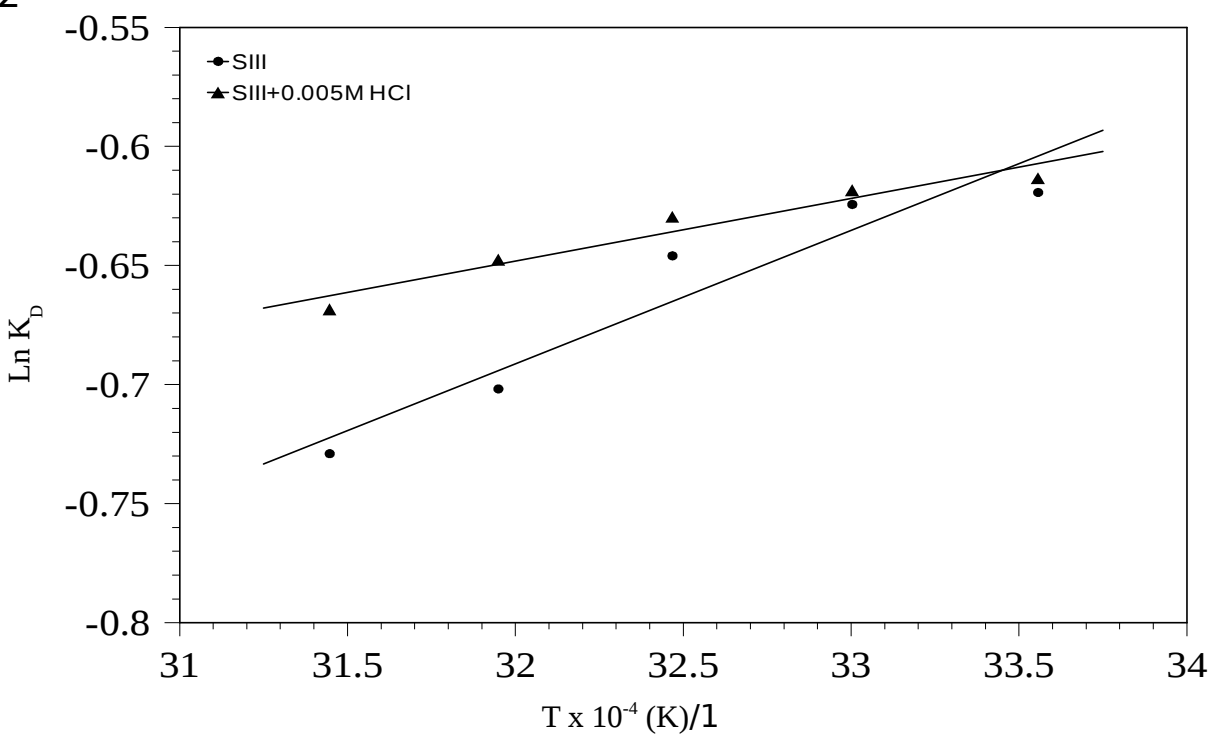

Fig. 8. Van't Hoff plot of adsorption equilibrium constant $K_{D}$ of copper metal ion on SIII in the absence and in the presence of $0.005 \mathrm{M} \mathrm{HCl}$.

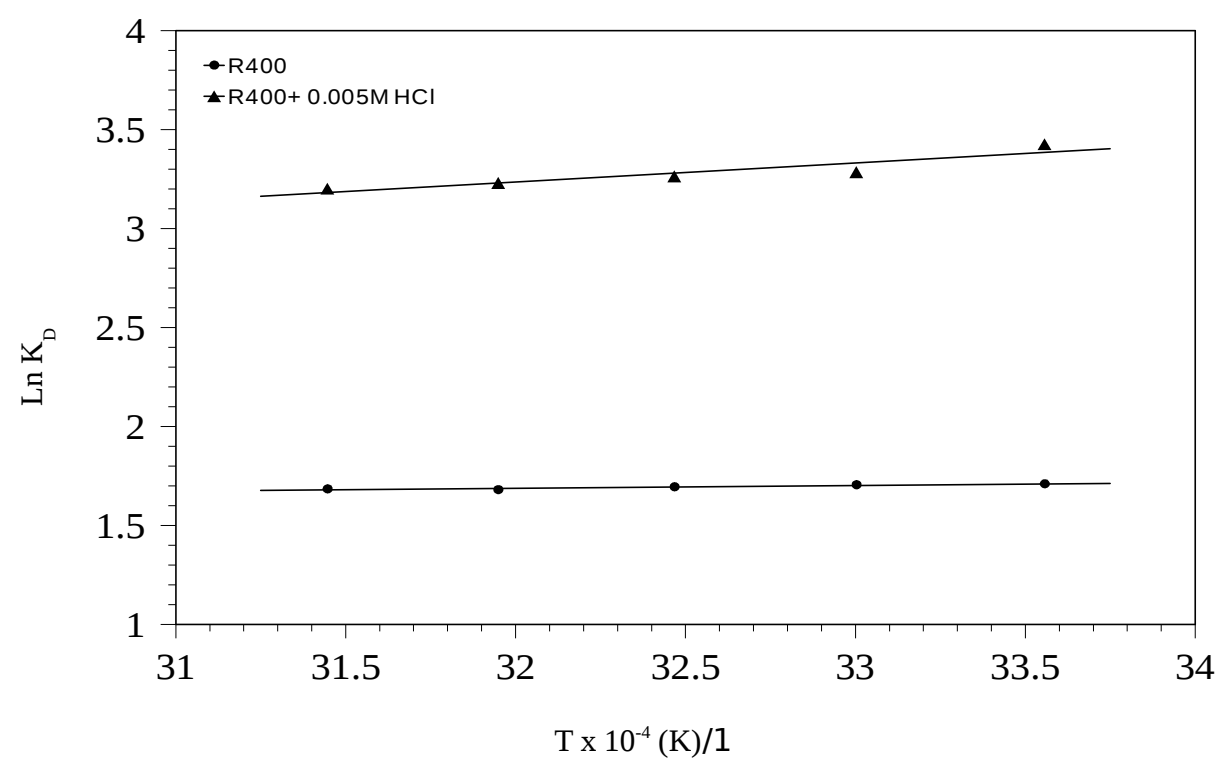

Fig. 9. Van't Hoff plot of adsorption equilibrium constant $K_{D}$ of copper metal ion on . $\mathrm{R} 400$ in the absence and in the presence of $0.005 \mathrm{M} \mathrm{HCl}$ 
KINETICS AND THERMODYNAMIC STUDIES ON REMOVAL ... 123 
and present of $0.005 \mathrm{M} \mathrm{HCl}$, and that the positive value of $T \Delta \mathrm{S}^{\circ}$ has to be larger than $\Delta H^{\circ}$. The positive value of $\Delta S^{\circ}$ in $\mathrm{R} 400$ in absence and presence of $\mathrm{HCl}$ suggests increased randomness at the solid/solution interface with some structural changes in the adsorbate and the adsorbent and an affinity of the adsorbents towards $\mathrm{Cu}(\mathrm{II})$ ions. The positive $\Delta \mathrm{S}^{\circ}$ value also corresponds to an increase in the degree of freedom of the adsorbed species [45].

The negative value of $\Delta \mathrm{H}^{\circ}$ for $\mathrm{Cu}(\mathrm{II})$ ions onto all adsorbates as shown in Table 3 indicates exothermic nature of adsorption. According to Alkan et al. [48], enthalpy change due to chemisorption takes value between 40 and $120 \mathrm{~kJ} \mathrm{~mol}^{-1}$, which is larger than that due to physisorption. Therefore, the low value of heat of adsorption obtained in this study indicates that adsorption is likely due to physisorption. The negative value of entropy change, $\Delta \mathrm{S}^{\circ}$, of SIII, and SIII+HCl, shows a decreased disorder at the solid/liquid interface during copper adsorption.

The negative value of free energy change, $\Delta \mathrm{G}^{\circ}$, is an indication of a spontaneous process whereby no energy input from outside of the system is required.

Table 3. Thermodynamic parameters of the adsorption of copper metal ions by SIII and $\mathrm{R} 400$ in the absence and in the presence of $0.005 \mathrm{M} \mathrm{HCl}$.

\begin{tabular}{cccccc}
\hline & Temp $(\mathrm{K})$ & $\mathrm{K}_{\mathrm{D}}$ & $\begin{array}{c}\Delta \mathrm{H}^{\circ} \\
(\mathrm{kJ} / \mathrm{mole})\end{array}$ & $\Delta \mathrm{S}^{\circ}(\mathrm{J} / \mathrm{mole})$ & $\begin{array}{c}\Delta \mathrm{G}^{\circ} \\
(\mathrm{kJ} / \mathrm{mole})\end{array}$ \\
\hline \multirow{3}{*}{ SIII } & 298 & 0.538 & & -20.77 & 1.54 \\
& 303 & 0.536 & & -20.56 & 1.57 \\
& 308 & 0.524 & -4.66 & -20.49 & 1.65 \\
& 313 & 0.496 & & -20.71 & 1.83 \\
& 318 & 0.482 & & -20.70 & 1.93 \\
\hline \multirow{2}{*}{ SIII + } & 298 & 0.542 & & -12.44 & 1.52 \\
$0.005 \mathrm{MCl}$ HCl & 303 & 0.539 & & -12.36 & 1.56 \\
& 308 & 0.533 & -2.19 & -12.34 & 1.61 \\
& 313 & 0.523 & & -12.37 & 1.69 \\
& 318 & 0.513 & & -12.44 & 1.77 \\
\hline \multirow{2}{*}{ R400 } & 298 & 5.526 & & 10.21 & -4.24 \\
& 303 & 5.500 & & 10.24 & -4.29 \\
& 308 & 5.443 & -1.19 & 10.21 & -4.34 \\
\hline R400 + & 313 & 5.366 & & 10.16 & -4.37 \\
$0.005 \mathrm{M}$ & 318 & 5.387 & & 10.25 & -4.45 \\
\hline HCl & 298 & 30.755 & -8.00 & 1.62 & -8.49 \\
& 303 & 26.711 & & 0.90 & -8.28 \\
& 308 & 26.154 & & 1.15 & -8.36 \\
& 313 & 25.284 & & 1.28 & -8.41
\end{tabular}




\section{KINETICS AND THERMODYNAMIC STUDIES ON REMOVAL . . 125

\begin{tabular}{llll}
\hline 318 & 24.562 & & \\
& &
\end{tabular}

\section{Conclusion}

The present study has demonstrated that rice straw and its ash possess the adsorption capacity for removal of copper metal ions in absence and presence of different concentration of hydrochloric acid solution. The following are the conclusions arrived from this study.

1. Copper showed higher adsorption capacity and rate in absence and low concentration of hydrochloric acid solutions.

2. Experimental data were better described by pseudo-second order model as evident from correlation coefficient values $\left(r^{2}\right)$

3. Thermodynamic parameters such as standard free energy $\left(\Delta G^{\circ}\right)$, enthalpy $\left(\Delta H^{\circ}\right)$ and entropy $\left(\Delta S^{\circ}\right)$ were calculated for predicting the nature of adsorption. The negative value of $\Delta \mathrm{H}^{\circ}$ for $\mathrm{Cu}(\mathrm{II})$ ions onto all adsorbates indicates exothermic nature of adsorption.

4. Rice straw and its ash can be used as an effective natural biosorbent for the economic treatment of wastewater containing $\mathrm{Cu}(\mathrm{II})$.

\section{References}

1. C.J. WILLIAMS, D. ADERHOLD, G.J. Edyvean, Comparison between biosorbents for the removal of metal ions from aqueous solutions, Water Res. 32 (1998) 216-224.

2. A. OZER, D. ÖZER, A. ÖZER, The adsorption of copper(II) ions onto dehydrated wheat bran (DWB): determination of the equilibrium and thermodynamic parameters, Process Biochem. 39 (2004) 2183-2191.

3. G. DÖNMEZ, Z. AKSU, The effect of copper(II) ions on the growth and bioaccumulation properties of some yeasts, Process Biochem. 35 (1999) 135-142.

4. M. AJMAL, A.H. KHAN, S. AHMAD, A. AHMAD, Role of sawdust in the removal of copper(II) from industrial wastes, Water Res. 32 (10) (1998) 3085-3091.

5. H. BENAÏSSA, M.A. ELOUCHDI, J.Chem. Eng. 46 (2007) 614-622

6. W.S. W. NGAH, M.A.K.M. HANAFIAH, J. Biochem. Eng. 39 (2008) 521-530

7. C.W. CHEUNG, C.F. PORTER, G. MCKAY, Sorption kinetics for the removal of copper and zinc from effluents using bone char, Sep. Purif. Technol. 19 (1997) 55-64.

8. V. C. TATY-COSTODES, H. FAUDUET, C. PORTE, A. Delacroix, Removal of Cd(II) and $\mathrm{Pb}(\mathrm{II})$ ions from aqueous solutions by adsorption onto sawdust of Pinus sylvestris, $\mathrm{J}$. Hazard. Mater. B 105 (2003) 121-142.

9. N. SHARMA, K. KAUR, S. KAUR, J. Hazard. Mater. 163 (2009) 1338-1344 
10. T. K. NAIYA, P. CHOWDHURY, A. K. BHATTACHARYA, S. K. DAS, J. Chem. Eng.148 (2009) 68-79

11. Z. REDDAD, C. GERENTE, Y. ANDRES, P.L. CLOIREC, Adsorption of several metal ions onto a low-cost biosorbent: kinetic and equilibrium studies, Environ. Sci. Technol. 36 (2002) 2067-2073.

12. Y. JIANG, H. PANGA, B. LIAO, J. Hazard. Mater. 164 (2009) 1-9

13. N. SHARMA, B. KAREER, A. SHARMA, Adsorption study for removal of $\mathrm{Zn}^{2+}$ and $\mathrm{Ni}^{2+}$ ions from aqueous solution using rice (Oryza sativa) husk, J. Environ. Agric. Food Chem. 6 (8.) (2007).

14. N. SHARMA, B. KAREER, Utilisation of rice (Oryza sativa) husk for removal of Co(II) ions from waste water, J. Agric. Biol. Res. 22 (2) (2006) 115-127.

15. N. SHARMA, A. THAKUR, U.S. SHIVHARE, M. KAUR, Kinetic and equilibrium studies of adsorption of $\mathrm{Cu}^{2+}$ ions on rice husk, Asian J. Chem. 18 (1) (2006) 615-620.

16. T.K. NAIYA, A.K. BHATTACHARYA, S. MANDAL, S.K. DAS, J. Hazard. Mater.163 (2009) 1254-1264

17. H. YE, Q. ZHU, D. DU, BIORES. Technol. 101 (2010) 5175-5179

18. E.I. EL-SHAFEY, J. Hazard. Mater. 175 (2010) 319-327

19. U. KUMAR, M. BANDYOPADHYAY, Sorption of cadmium from aqueous solution using pretreated rice husk, Biores. Technol. 97 (2006) 104-109.

20. A.B. PEREZ-MARIN, V.M. ZAPATA, J.F. ORTUNO, M. AGUILAR, J. SAEZ, M. LLORENS, Removal of cadmium from aqueous solutions by adsorption onto orange waste, J. Hazard. Mater. 139 (1) (2007) 122-131.

21. F.Y. WANG, H. WANG, J.W. MA, J. Hazard. Mater, 177, 1-3, 15 (2010) 300-306

22. K.N. GHIMIRE, J. Inoue, K. Inoue, H. Kawakita, K. Ohto, Adsorptive separation of metal ions onto phosphorylated orange waste, Sep. Sci. Technol. 43 (2008) 362-375.

23. R. APIRATIKUL, P. PAVASANT, Biores. Technol. 99 (2008) 2766-2777

24. A. DEMIRBAS, J. Hazard. Mater. 157 (2008) 220-229

25. E. CHOCKALINGAM, S. SUBRAMANIAN, Chemosphere 62 (2006) 699-708

26. M. AJMAL, A.H. KHAN, S. AHMAD, A. AHMAD, Role of sawdust in the removal of copper(II) from industrial wastes, Water Res. 32 (1998) 3085-3091.

27. Y. NUHOGLU, E. OGUZ, Removal of copper(II) from aqueous solutions by biosorption on the cone biomass of Thuja orientalis, Process Biochem. 38 (2003) 1627-1631.

28. B.M.W.P.K. AMARASINGHE, R.A. WILLIAMS, J. Chem. Eng. 132 (2007) 299-309

29. F. ASADI, H. SHARIATMADARI, N. MIRGHAFFARI, J. Hazard. Mater. 154 (2008) 451-458 
30. J. FEBRIANTO, A. N. KOSASIH, J. SUNARSO, Y. JU, N. INDRASWATI, S. ISMADJI, J. Hazard. Mater. 162 (2009) 616-645

31. M. S. RAHMAN, M. R. ISLAM, J. Chem. Eng. 149 (2009) 273-280

32. C. G. ROCHA, D. A. M. ZAIA, R. V. DA SILVA ALFAYA, A. A. DA SILVA ALFAYA, J. Hazard. Mater. 166 (2009) 383-388.

33. A. BENHAMMOU, A. YAACOUBI, L. NIBOU, B. TANOUTI, J. Colloid and Interface Science 282 (2005) 320-326

34. European Journal of Scientific Research ISSN 1450-216X Vol.24 No.3 (2008), pp.451462

35. N. KANNAN, M.M. SUNDARAM, Kinetics and mechanism of removal of methylene blue by adsorption on various carbons- a comparative study, Dyes Pigments 51 (1) (2001) $25-40$.

36. Y.S. HO, G. MCKAY, Kinetic models for the sorption of dye from aqueous solution by wood, J. Environ. Sci. Health. Part B. Process Safety Environ. Protection 76 (B2) (1998) 183-191.

37. N. DAS, P. PATTANAIK, R. DAS, Defluoridation of drinking water using activated titanium rich bauxite, J. Colloid Interface Sci. 292 (2005) 1-10.

38. M.G. SUJANA, R.S. THAKUR, S.B. RAO, Removal of fluoride from aqueous solution by using alum sludge, J. Colloid Interface Sci. 206 (1998) 94-101.

39. WEBER, W.J., MORRIS, J.C., 1962. Advance in water pollution research: removal of biological resistant pollutions from wastewater by adsorption. In: Proceedings of the International Conference on Water Pollution Symposium. Pergamon Press, Oxford.

40. ÖZCAN, A.S. ÖZCAN, Adsorption of Acid Red 57 from aqueous solutions onto surfactant-modified sepiolite, J. Hazard. Mater. 125 (1-3) (2005) 252-259.

41. A.S. ÖZCAN, Ş. TETIK, A. ÖZCAN, Adsorption of acid dyes from aqueous solutions onto sepiolite, Separ. Sci. Technol. 39 (2) (2004) 301-320.

42. K.G. BHATTACHARYYA, A. SHARMA, Azadirachta indica leaf powder as an effective biosorbent for dyes: a case study with aqueous Congo Red solutions, J. Environ. Manage. 71 (3) (2004) 217-229.

43. J.P. CHEN, S.WU, K.H. CHONG, Surface modification of a granular activated carbon by citric acid for enhancement of copper adsorption, Carbon 41 (10) (2003) 1979-1986.

44. C. Raymon, Chem. Thermodynamic, McGraw-Hill, Boston, 1998, p. 737.

45. M. ALKAN, O“. DEMIRBAS, S. C, ELIKC,apa, M. Dog־an, Sorption of acid red 57 from aqueous solution onto sepiolite, J. Hazard. Mater. B116 (2004) 135-145. 